\title{
Groundwater contribution to the river flow for the upper course of the Osam River based on two baseflow separation methods
}

\author{
Tanya Vasileva ${ }^{1}$, Tatiana Orehova ${ }^{1}$, Kamelia Kroumova ${ }^{2}$ \\ ${ }^{1}$ Geological Institute, Bulgarian Academy of Sciences, Acad. G. Bonchev Str., Block 24, 1113 Sofia, Bulgaria; \\ e-mails: tanyav@geology.bas.bg,tvorehova@gmail.com \\ ${ }^{2}$ National Institute of Meteorology and Hydrology, 66 Tsarigradsko Shose Blvd, 1784 Sofia, Bulgaria; \\ e-mail: Kamelia.Kroumova@meteo.bg
}

(Accepted in revised form: November 2017)

\begin{abstract}
The study area in the upper part of the Osam River basin (central North Bulgaria) is characterized by highly variable mountain relief and diversified geological and hydrogeological conditions. Mesozoic clayeyterrigenous sediments are widespread in the area. Triassic and Jurassic carbonate rocks are developed locally, mainly in the upper part of the river basin. The mountainous landscape is dominated by old-forest vegetation communities. Both fissured-porous and karst groundwater systems are developed in the area. The groundwater is recharged mostly from precipitation and forms baseflow of streams. The aim of the study is to evaluate the groundwater contribution to the river flow for the catchment area of the Cherni Osam River and the Beli Osam River, forming the upper course of the main Osam River. For this purpose, two baseflow separation methods are used (local minimum method and digital filter of Eckhardt). Daily data for the river stream gages for the period 2009-2015 were processed. The baseflow for the studied catchments shows higher value for the Cherni Osam River basin and almost twice as lower value for the Beli Osam River basin. These results are most probably largely related to both the karst area and the forest cover. The digital filter developed by Eckhardt is considered as the most reliable for baseflow separation for the study area.
\end{abstract}

\begin{abstract}
Vasileva, T., Orehova, T., Kroumova, K. 2017. Groundwater contribution to the river flow for the upper course of the Osam River based on two baseflow separation methods. Geologica Balcanica $46(2), 73-82$.
\end{abstract}

Keywords: groundwater, baseflow separation, digital filter method, Osam River basin, Bulgaria.

\section{INTRODUCTION}

The study area covers the upper catchment area of the Osam River with an area of $565 \mathrm{~km}^{2}$ (Fig. 1). It is located in the high parts of central North Bulgaria (Fore-Balkan and Balkan Mts), and its eastern part belongs to the Troyan Mountain. After the inflow of the Cherni Osam River into the Beli Osam River, north of the town of Troyan, the Osam River continues to the north through the Balkan mountain range and the Danube Plain until its inflow into the Danube River.

The study area is built mostly of Mesozoic clayeyterrigenous and, locally, carbonate sediments (including limestones and dolostones), and is characterized by a complex tectonic structure with faulting and thrusting. In the upper mountain part, numerous welldeveloped karst forms can be identified. The aim of the research is to evaluate the groundwater contribution to the river flow for the catchment areas of the Cherni and Beli Osam Rivers, forming the upper course of the main Osam River.

\section{DESCRIPTION OF THE STUDY AREA}

The relief of the study area is mountainous, highly dissected by gorges, locally with vertical rocks up to $150 \mathrm{~m}$ high. The altitudes vary from about $300 \mathrm{~m}$ asl to $2209 \mathrm{~m}$ asl. Within the upper course of the Cherni Osam River, karst landscape is developed, with numerous negative karst forms (caves, shafts, etc.).

In the mountains, the landscape is dominated by old-forest vegetation communities, mainly of beech and, to a lesser extent, coniferous forests. Based on the CORINE LandCover data (CLC, 2012), the densest beech forests are found in the upper course of the Cherni Osam River. No substantial changes have been identified for the period of 2000 to 2012 in the 


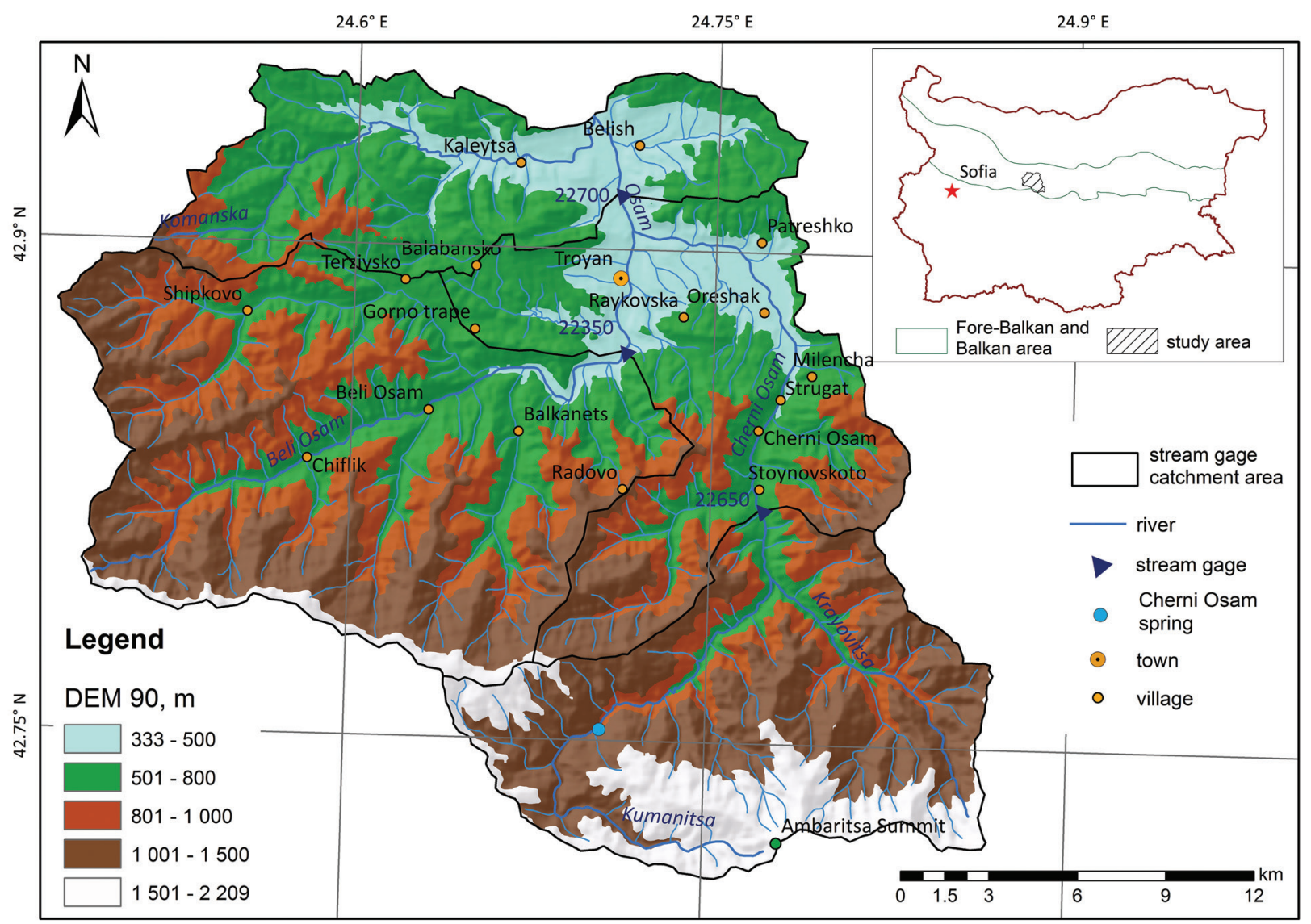

Fig. 1. Location and DEM of the study area.

area (Table 1). Due to the specific natural conditions of this area, the biosphere Steneto Reserve (Troyan Mountain, part of the Balkan Mountains Ridge) was established in 1979 within the boundaries of the Central Balkan National Park.

The mean annual precipitation sums are in the range of $766 \mathrm{~mm}$ for Troyan, $1326 \mathrm{~mm}$ for Ambarit$\mathrm{sa}$, and $1057 \mathrm{~mm}$ for Cherni Osam Village (Koleva and Peneva, 1990). The high elevations are the reason for relatively large precipitation amounts, which are transformed into permanent or temporary surface runoff of the rivers Beli Osam, Cherni Osam and their tributaries. Some of the streams lose their waters, and a part of the precipitation sinks underground due to exposed karstified carbonate rocks.

\section{Geological and hydrogeological settings}

The study area is characterized by complex geological setting with faulting and thrusting. Two large structural areas are defined in the upper part of the Osam River basin: the Fore-Balkan-Balkan and Srednogorie area. Metamorphic rocks of Precambrian and Cambrian ages, Permian volcanic rocks and Mesozoic sediments crop out (Cheshitev et al., 1993, 1994).

The relief and the geological framework predetermine to a great extent the distribution and circulation of surface and groundwater. In the study area, fractured, fissured-porous, and karst groundwater systems are developed (Fig. 2).

Table 1

Percent values of forest cover in the watersheds (CLC 2000/2012)

Watershed at stream gage No.

\begin{tabular}{lccc}
\cline { 2 - 3 } Forest types & 22350 & 22650 & 22700 \\
\hline Broadleaved, mixed and coniferous forests & $52.9 / 55.7$ & $72.8 / 72.6$ & $58.3 / 59.6$ \\
The same with transitional woodland-shrub & $55.9 / 55.8$ & $78.9 / 79.5$ & $61.8 / 64.1$ \\
\hline
\end{tabular}




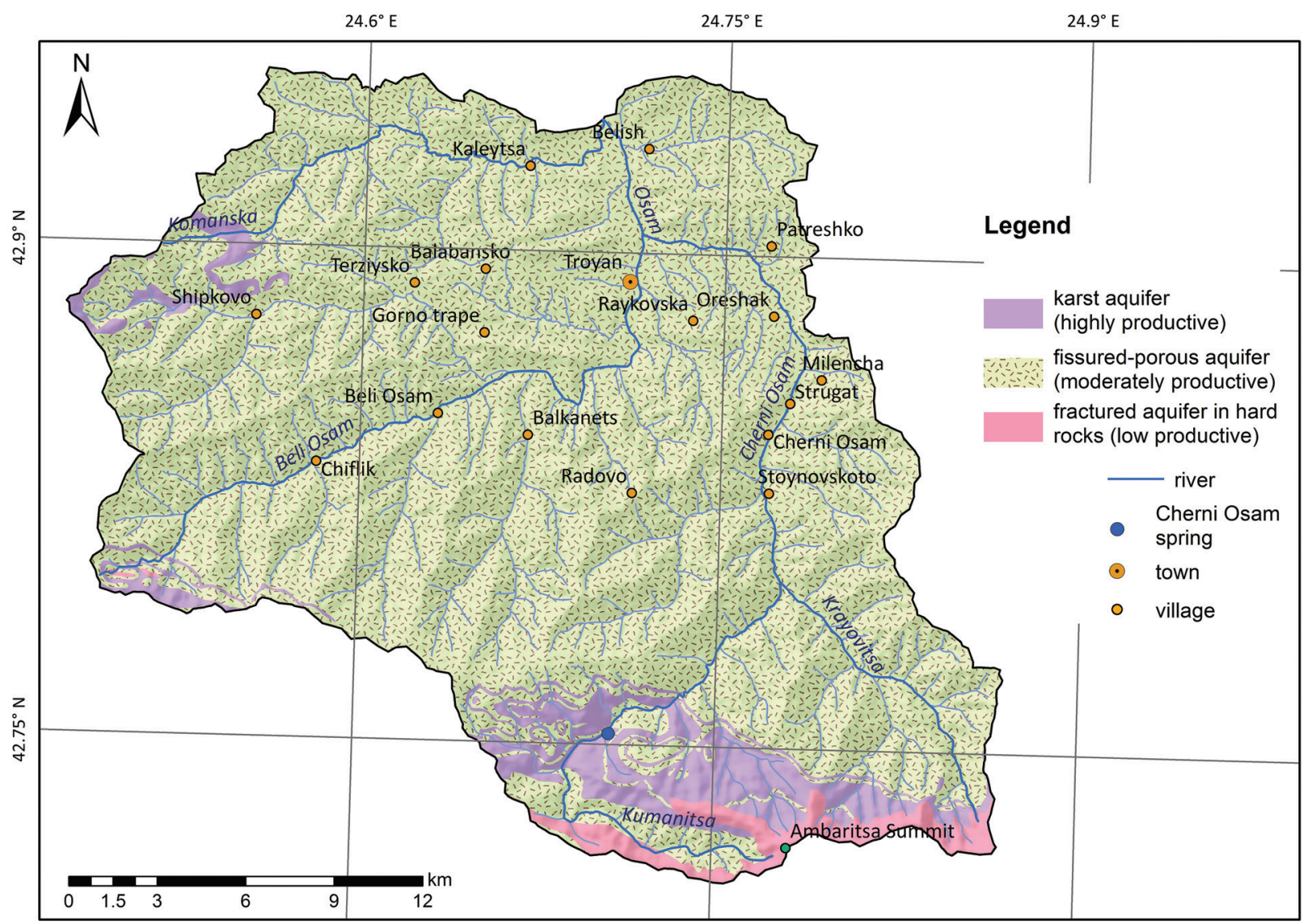

Fig. 2. Spatial distribution of the groundwater systems.

Groundwater in the area is related mainly to weathering zones of the rock complexes of Paleozoic and Mesozoic age. Hard rocks (granites and granitegneisses) are locally developed in the high southern part of the study area. The largest area is covered by Mesozoic sediments (marlstones, mudstones, siltstones, sandstones, and conglomerates) with related fissured-porous aquifers. The recharge of the fractured and fissured-porous groundwater systems is on account of rainfalls and snowmelt. Natural discharge of these aquifers occurs into streams and through numerous springs with low discharge.

Outcrops of calcareous sediments on the land surface are of particular importance. Carbonate terrains cover a relatively small part in the southern mountainous study area (about 7\%) but have a significant impact on formation of surface water and groundwater, especially in the Cherni Osam River basin.

In this part of the area, the major karst aquifer is located, which is built of karstified limestones and dolostones of the Triassic carbonate complex. It is the Cherni Osam karst basin (Boyadjiev, 1964), characterized by a labyrinth of galleries, caves and shafts. More than 60 caves have been identified, but most of them are dry, without running waters (Benderev,
2006). Three of the caves are over $1000 \mathrm{~m}$ long: the Kumanitsa, Malkata Yama and Varlata caves. Five of the caves are more than $100 \mathrm{~m}$ in depth.

The Jurassic carbonate complex lies between two low-permeable complexes: one of them of Early-Middle Jurassic age and the other of Late Jurassic to Early Cretaceous age. It crops out on the land surface in the form of narrow strips and is characterized by deep karstification. The Jurassic carbonate complex is isolated from the main Triassic aquifer and forms a separate karst-fissured groundwater systems. The deepest cave of Bulgaria, Raichova Dupka (-387 m depth), found in the Troyan Mountain, is formed on the contact of Middle Jurassic limestones with terrigenouscarbonate rocks.

Karst aquifers in the Middle and Upper Jurassic sediments are of limited occurrence, as well as those related to the Upper Cretaceous sediments. It is noteworthy that several terrigenous formations contain calcareous intercalations, with related karst groundwater.

The recharge of karst groundwater is on account of atmospheric precipitation, perennial and temporary streams, and local fissured groundwater. The discharge occurs by means of streams and through karst springs, some of them with high discharge. 
The well-developed karst in the channel bed causes drying up of the Cherni Osam River in its upper course and formation of an underground karst stream (Antonov and Danchev, 1980).

The largest karst spring in the study area (named Cherni Osam) is located in the Steneto Reserve. It is formed on the account of waters of the Kumanitsa River (one of the right tributaries of the Cherni Osam River) that sinks down through the limy channel bed (Kumanitsa Cave). The groundwater flow is related to the Triassic carbonate complex, which is barraged by the Paleozoic rocks, and appears on land surface as a spring (Fig. 3) with a flow rate from $500 \mathrm{l} / \mathrm{s}$ to $3000 \mathrm{l} / \mathrm{s}$ (see Antonov and Danchev, 1980). According to data obtained from the Danube River Basin Directorate, the maximum measured flow rate is $3590 \mathrm{l} / \mathrm{s}$. Radulov (2002) provided more details on the geological structure and hydrological conditions of the Cherni Osam karst basin, which is also drained from other springs with a lower flow.

The groundwater in the area is used for domestic water supply and power generation.

\section{METHODS AND DATA}

The groundwater contribution to the river flow in the upper course of the Osam River was evaluated based on baseflow separation of the river runoff at three stream gages in the area, operated by the National Institute of Meteorology and Hydrology (Fig. 1). Daily data for the period 2009-2015 were processed.
Streamflow at any time $\mathrm{Q}(\mathrm{t})$ is composed of the sum of quickflow $Q_{q}(t)$ and baseflow $q_{b}(t)$ :

$$
Q(t)=Q_{q}\left(t_{0}\right)+q_{b}\left(t_{0}\right)
$$

Quickflow (or direct runoff) results from rainfall events, and baseflow comes from slow storage reservoirs (mainly groundwater aquifers).

Baseflow separation analysis (that defines contribution of groundwater in streamflow) was carried out by two methods: Local Minimum Method and Recursive Digital Filter Method, using software products $\mathrm{BFI}+$ and WHAT, respectively.

The baseflow index BFI is defined as a relation of baseflow to the total streamflow for a long-lasting period.

\section{Local minimum method}

One of the well-known baseflow separation techniques is the local minimum method based on filtering daily streamflow data by finding minima within predefined non-overlapping consecutive intervals $\mathrm{N}$ (typically $\mathrm{N}=5$ days) and connecting them (Sloto and Crouse, 1996).

Wahl and Wahl (1995) proposed optimization of this value by computing the long-term average BFI values for a range of $\mathrm{N}$ values $(\mathrm{N}=1,2, \ldots, 30$ days) and then identifying the break point in the relationship between these BFI values and N, which indicates the required value of the parameter BFI. Miller et al.

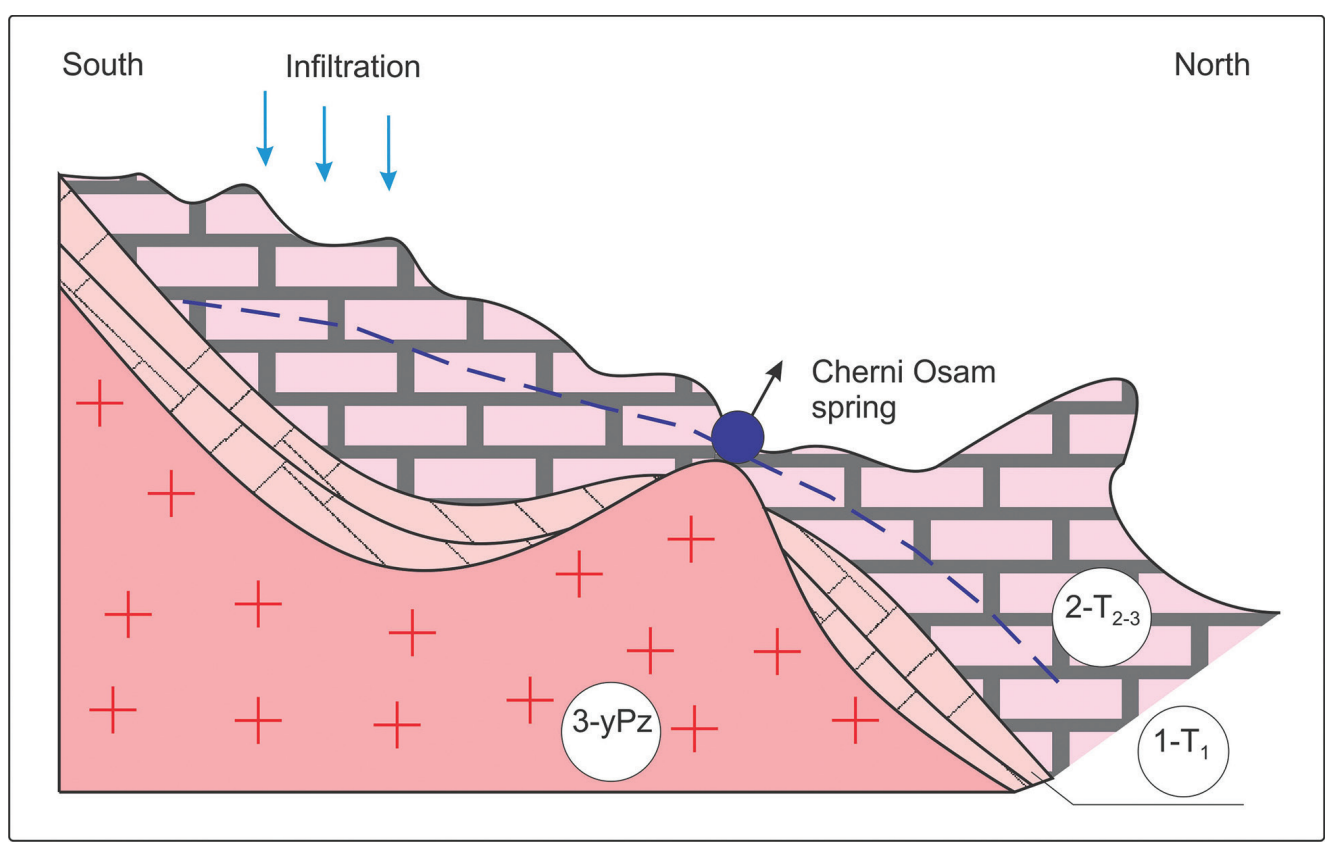

Fig. 3. Schematic hydrogeological cross-section for the basin of the Cherni Osam spring (after Antonov and Danchev, 1980): 1 - Lower Triassic sandstones with little fissured groundwater; 2 - Middle Triassic karst limestones and dolostones (strongly aquiferous); 3 - granodiorites. 
(2015) approved and used this approach. Such modification gives better estimates of BFI values, which avoids their overestimation.

The software BFI+, developed by Gregor (2010), provides baseflow separation based on several techniques, including the local minimum method.

\section{Recursive Digital Filter Method}

The automated baseflow separation by Digital Filtering Method (based on the linear storage model) has been developed by Eckhardt (2005) and requires two parameters. The groundwater recession parameter $(a)$ is defined based on the recession analysis from the equation:

$$
Q(t)=Q\left(t_{0}\right) \cdot e^{-a \cdot\left(t-t_{0}\right)}=Q\left(t_{0}\right) \cdot K_{b}^{\left(t-t_{0}\right)}
$$

where $Q(t)$ is the stream flow at any time $(t), Q\left(t_{0}\right)$ is the stream flow at the beginning of the recession $\left(t_{0}\right)$, and $K_{b}$ is the recession constant:

$$
K_{b}=\exp \left[-a \cdot\left(t-t_{0}\right)\right]
$$

The baseflow separation is realized based on filter equation (Eckhardt, 2005):

$$
q_{b(i)}=\frac{\left(1-B F I_{\max }\right) \cdot K_{b} \cdot q_{b(i-1)}+\left(1-K_{b}\right) \cdot B F I_{\max } \cdot Q_{i}}{1-K_{b} \cdot B F I_{\max }}
$$

where $q_{b(i)}$ is the filtered baseflow at time step $i ; q_{b(i-I)}$ is the filtered baseflow at the previous time step $i-1$, $Q_{i}$ is the total stream flow at time step $i ; K_{b}$ is the filter parameter equal to the recession constant; and $\mathrm{BFI}_{\max }$ is the maximum value of the baseflow index.

This second parameter, $\mathrm{BFI}_{\max }$, is non-measurable, but Eckhardt (2005), based on preliminary results, suggested the values as follows: $\mathrm{BFI}_{\max }=0.80$ for perennial streams with porous aquifers; $\mathrm{BFI}_{\max }=0.50$ for ephemeral streams with porous aquifers; and $\mathrm{BFI}_{\max }=$ 0.25 for perennial streams with hard rock aquifers. According to Hubbar and Zell (2013), the BFI $\mathrm{max}_{\text {max }}$ parameter is presumably related to the average area-weighted aquifer characteristics. For heterogeneous geological setting, they proposed using an area-weighted value for $\mathrm{BFI}_{\max }$.

Zinn and Harvey (2003) reminded that, for spatially heterogeneous sediments, the effective hydraulic conductivity lies within the arithmetic mean (the upper bound) and the harmonic mean (the lower bound), which correspond to flow through a perfectly layered system, parallel and perpendicular to the layering, respectively. The geometric mean lies between these limits (bounds). Based on their experiments, they gave evidence that "in the field with connected low-conductivity regions, the effective conductivity is below the geometric mean". As BFI is related to the baseflow formation (i.e., groundwater discharge into streams, which depends on the hydraulic conductivity), these conclusions would also be valid for the case under consideration.

Lim et al. (2005) incorporated the Eckhardt Filter into the Web based Hydrograph Analysis Tool (WHAT) system.

\section{RESULTS}

A digital terrain model (SRTM 90) was used to delineate the catchment areas to the stream gages (Fig. 1).

The baseflow separation was realized by the two methods presented in the previous section. Daily streamflow data for the period of January 2009 to December 2015 were processed for the three stream gages.

\section{Local minimum method}

The software BFI+ (Gregor, 2010) was used for the baseflow separation based on the local minimum method. Initially, the standard value $\mathrm{N}=5$ days was used. The BFI values obtained for the two catchment areas are very high and almost equal $(\mathrm{BFI}=0.50)$, which is unacceptable as they have rather different lithological compositions and river flow regimes.

The modified technique described in the previous section was then applied. For this purpose, the longterm average BFI values were calculated for a range of $\mathrm{N}$ values, and the breakpoints were identified based on the graphs. Thus, the optimized values of BFI were obtained. The break-point in the piece-wise linear relationship for stream gages No. 22350 and No. 22700 was identified at $\mathrm{N}=5.64$. The optimal $\mathrm{N}$-parameter value for this site was set to 6 days (the nearest integer value). For the stream gage No. 22650, N equals 7.38. The optimal $\mathrm{N}$-parameter value in this case was set to 7 days (Fig. 4).

The obtained results from the baseflow separation by the local minimum method are presented in Table 2 and Fig. 5 (for stream gage No. 22650).

It is noteworthy that the BFI values obtained for the catchment area with karst basin (stream gage No. 22650) are lower compared to those with predominantly fissured rocks (stream gage No. 22350), which is in contradiction with hydrogeological practice.

The results from baseflow separation for the same catchments presented by Spasov (1966) gave more acceptable values, especially for the baseflow indices (Table 3).

\section{Recursive digital filter method}

The recursive digital filter developed by Eckhardt (2005) requires two parameters [Eq. (4)]. Several recession periods (within the period 2009-2015) were identified and processed to obtain the recession constant value based on Eqs (2) and (3). 


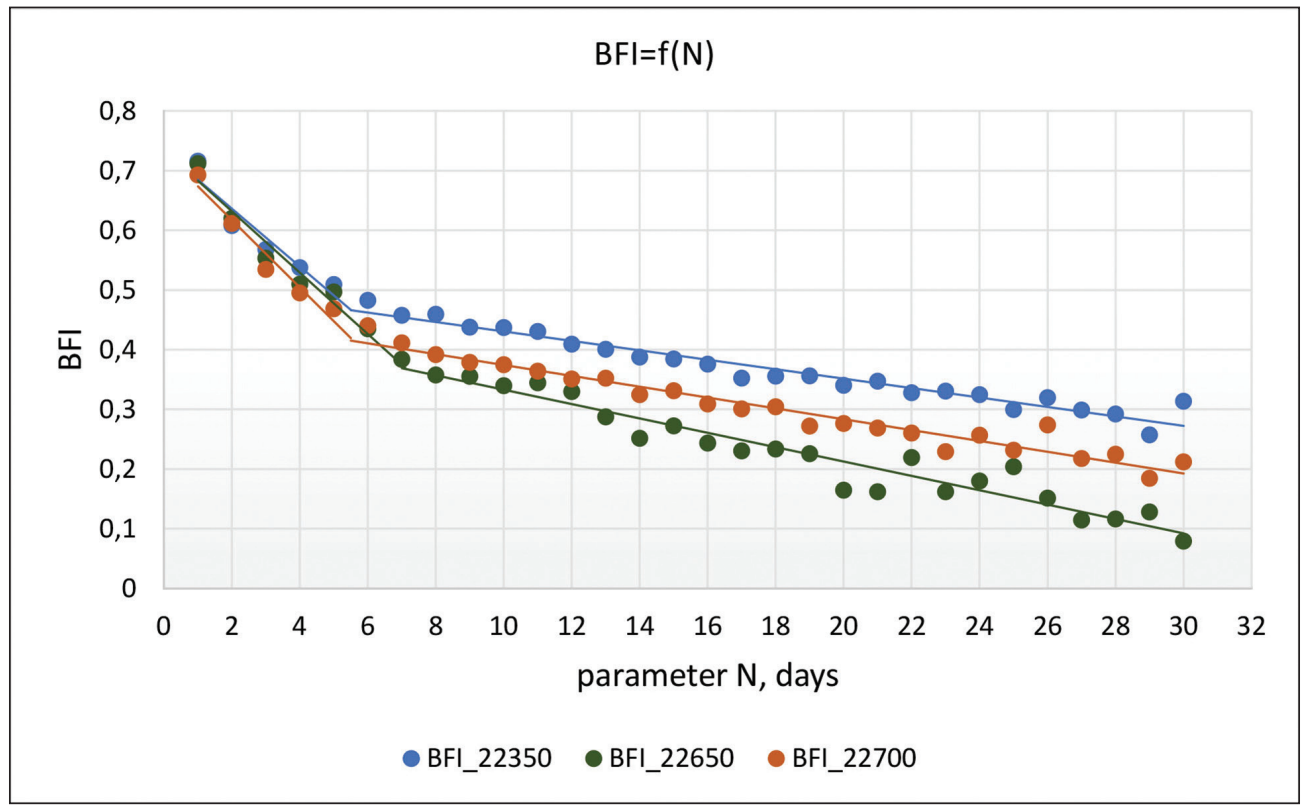

Fig. 4. Break-point analysis for the stream gages.

Table 2

Baseflow separation by the local minimum method (period 2009-2015)

\begin{tabular}{lccccc}
\hline Stream gage No. & $F, \mathrm{~km}^{2}$ & $Q, \mathrm{~m}^{3} / \mathrm{s}$ & $Q_{b}, \mathrm{~m}^{3} / \mathrm{s}$ & $Q_{b}, \mathrm{~mm} / \mathrm{yr}$ & BFI \\
\hline 22350 & 204.16 & 3.152 & 1.522 & 234.8 & 0.483 \\
22650 & 141.55 & 4.032 & 1.548 & 344.5 & 0.384 \\
22700 & 465.03 & 6.364 & 2.619 & 177.4 & 0.440 \\
\hline
\end{tabular}

Table 3

Baseflow separation for the period 1953-1959 (Spasov, 1966)

\begin{tabular}{lccc}
\hline Stream gage No. & $Q, \mathrm{~mm} / \mathrm{yr}$ & $Q_{b}, \mathrm{~mm} / \mathrm{yr}$ & BFI \\
\hline 22350 & 658 & 207 & 0.315 \\
22650 & 927 & 382 & 0.412 \\
22700 & 642 & 185 & 0.288 \\
\hline
\end{tabular}

The value of the parameter $\mathrm{BFI}_{\max }$ was defined according to Eckhardt's (2005) guidelines, described in the previous section. Within the study area, karst, fissured, and fissured-porous groundwater systems are developed. As a result, the area is characterized by high spatial heterogeneity, mostly due to the presence of karstified rocks (Fig. 2).

In line with the suggestions of Hubbar and Zell (2013), for the study area, the areal-weighted values for $\mathrm{BFI}_{\max }$ were calculated for each catchment area. It was taken into account that using arithmetic mean would overestimate the effective value of $\mathrm{BFI}_{\max }$ as low values prevail in the area, and the weighted harmonic mean value was used to calculate the effective value of $\mathrm{BFI}_{\max }$ for each catchment area.

The karst aquifers are characterized by three types of porosity: intergranular matrix porosity, fracture porosity, and large cavernous conduits (Martin and Screaton, 2001), and the respective value for $\mathrm{BFI}_{\max }$ was set to 0.80 . Hard rock with typical value $\mathrm{BFI}_{\max }$ $=0.25$ (granites and granite-gneisses) cover relatively small area. 

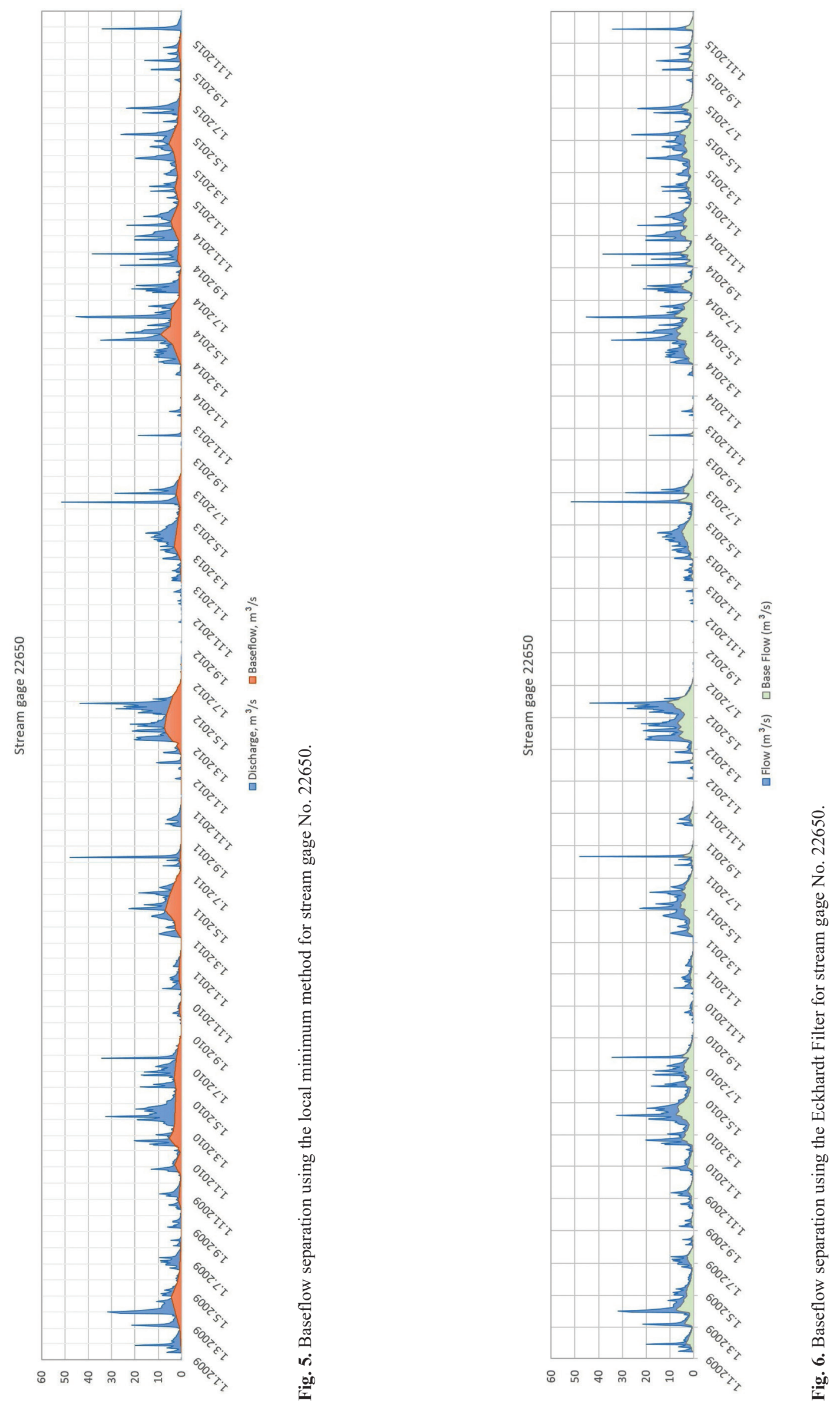
For the most widespread groundwater system in the area, namely the fissured-porous (built of sandstones, siltstones, conglomerates, and marls), an intermediate value for $\mathrm{BFI}_{\max }$ was set between this for porous media $(0.80)$ and hard rock $(0.25)$, calculated as harmonic mean value (about 0.381 ), following the above mentioned recommendations of Zinn and Harvey (2003), as the baseflow value depends on the hydraulic conductivity.

Both parameters for the Eckhardt Filter (recession constant and the area-weighted, values for $\mathrm{BFI}_{\max }$ ) are presented in Table 4.

The baseflow separation for the studied seven-year period was realized by the Eckhardt Filter with the help of WHAT software (Lim et al., 2005). The results are presented in Table 5 and Fig. 6.

\section{DISCUSSION}

The results obtained from the presented baseflow separation methods show reasonable values for the baseflow, but rather different BFI values (Tables 2, 3, 5).

Despite the applied optimization, the local minimum method provided acceptable results for BFI only for the Beli Osam River basin (stream gage No. 22350) that drains mainly fissured aquifers. The BFI value obtained for the Cherni Osam River basin (stream gage No. 22650), draining the Cherni Osam karst basin, are very low, which is in contradiction with the hydrogeological setting.

The baseflow separation by the digital filter method showed the BFI values that are in accordance with the hydrogeological settings of the studied catchment areas: a higher value for the Cherni Osam River basin (due to the influence of karst) and a lower value for the Beli Osam River (with a prevailing fissured-porous groundwater system). These reasonable results were achieved, owing to the areal-weighted harmonic mean value applied for $\mathrm{BFI}_{\max }$, an important input parameter for the Eckhardt filter. This digital filter method is considered as reliable for baseflow separation, provided that the input parameters are valid.

Spasov (1966) reported the baseflow and the BFI values for the catchments for the period from 1953 to 1959 (Table 3). The BFI values obtained from the present study deviate considerably from these values, but the baseflow values are almost identical. Possible causes of the deviations are: different baseflow separation method, specific meteorological conditions for the respective periods, or land cover changes. Generally, the baseflow values $\left(Q_{b}, \mathrm{~mm} / \mathrm{an}\right)$ obtained for the two periods are reasonable: rather high for the Cherni Osam River basin and lower (almost twice) for the Beli Osam River basin.

The widespread land cover type in the study area is old-forest vegetation dominated by beech and, to a lesser extent, coniferous trees (Table 1). In general, watersheds in mountain areas covered by forests are characterized by high values of baseflow and low flow (Price, 2011). Brogna et al. (2017), based on statistical analyses, showed significant positive relationship between basin forest cover and baseflow discharge. The results obtained for the study area are consistent with these research findings.

The available information is not sufficient to define the true values of the baseflow and the baseflow index for the studied catchments. The digital filter

Table 4

Parameters for the recursive digital filter

\begin{tabular}{l|c|c|c|c|c}
\hline $\begin{array}{l}\text { Stream } \\
\text { gage }\end{array}$ & $\begin{array}{c}\text { Recession } \\
\text { constant }\end{array}$ & \multicolumn{2}{|c|}{ Groundwater systems in \% of studied area } & \multicolumn{2}{c}{$\begin{array}{c}\text { Harmonic mean } \\
\text { area-weighted value }\end{array}$} \\
\hline No. & $K_{b}$ & karst & hard rock & fissured-porous & BFI $_{\max }$ \\
\hline 22350 & 0.9560 & 3.27 & 0.00 & 96.73 & 0.395 \\
22650 & 0.9220 & 22.08 & 9.55 & 68.37 & 0.461 \\
22700 & 0.9218 & 8.61 & 2.96 & 88.43 & 0.413 \\
\hline
\end{tabular}

Table 5

Baseflow separation by the recursive digital filter (period 2009-2015)

\begin{tabular}{lccccc}
\hline Stream gage No. & $F, \mathrm{~km}^{2}$ & $Q, \mathrm{~m}^{3} / \mathrm{s}$ & $Q_{b}, \mathrm{~m}^{3} / \mathrm{s}$ & $Q_{b}, \mathrm{~mm} / \mathrm{yr}$ & $\mathrm{BFI}$ \\
\hline 22350 & 204.16 & 3.152 & 1.220 & 188.2 & 0.387 \\
22650 & 141.55 & 4.032 & 1.806 & 401.9 & 0.448 \\
22700 & 465.03 & 6.364 & 2.602 & 176.2 & 0.409 \\
\hline
\end{tabular}


proposed by Eckhardt (2005) seems to be the wellfounded method that provides representative results for baseflow separation for the study area.

\section{CONCLUSIONS}

The study area located in the mountainous region of central North Bulgaria is characterized by widespread fissured-porous groundwater systems with locally distributed karst and fractured aquifers drained by the Osam River. The Cherni Osam karst basin, with well-developed karst and a large spring, belongs to the study area. Forested vegetation is the most common land cover in the study area, especially for the Cherni Osam River basin.

The groundwater contribution to the river flow for the upper course of the Osam River (for the period 2009-2015) was evaluated based on two baseflow separation methods: the local minimum method (by means of BFI+ software) and the recursive digital filter developed by Eckhardt (2005), using WHAT software (Lim et al., 2004, 2005). Despite the applied op- timization, the local minimum method did not provide acceptable results for the Cherni Osam River.

The second method (Eckhardt Filter), however, gave better results. Evaluation of the input parameters for this method is crucial, especially effective value of the maximal baseflow index $\mathrm{BFI}_{\max }$ for heterogeneous area. Important recommendations of different authors were taken into account in this relation, including using the areal-weighted harmonic mean value $\mathrm{BFI}_{\max }$.

The results obtained by the Eckhardt Filter are in good agreement with the specific features of the studied catchment areas: lower values both of the baseflow and for BFI for the Beli Osam River catchment at the town of Troyan (a predominantly fissured-porous groundwater system) and higher values for the Cherni Osam River at Stoynovska (with important karst aquifer). This method is considered reliable for baseflow separation, provided that the input parameters are valid.

The baseflow values for the studied catchments show higher baseflow value for the Cherni Osam River basin and lower (almost twice) for the Beli Osam River basin. These results are largely related to both the karst area and the forest cover.

\section{REFERENCES}

Antonov, H., Danchev, D. 1980. Groundwater in the Republic of Bulgaria. Tehnika, Sofia, 360 pp. (in Bulgarian).

Benderev, A. 2006. Some important karstic regions in Bulgaria. In: Beron, P., Daaliev, T., Jalov, Al. (Eds), Caves and Speleology in Bulgaria. Bulgarian Federation of Speleology, National Museum of Natural History, PenSoft, Sofia, $108-126$

Boyadjiev, N. 1964. The karst basins in Bulgaria and their ground waters. Bulletin of the Institute of Hydrology and Meteorology 2, 45-96.

Brogna, D., Vincke, C., Brostaux, Y., Soyeurt, H., Dufrêne, M., Dendoncker, N. 2017. How does forest cover impact water flows and ecosystem services? Insights from "real-life" catchments in Wallonia (Belgium). Ecological Indicators $72,675-685$.

Cheshitev, G., Nikolov, T., Milanova, V., Chontova, C. 1993. Geological Map of the Republic of Bulgaria in scale 1:100,000, Troyan Map Sheet. Committee on Geology, Company for Geophysical surveys and Geological mapping, Sofia.

Cheshitev, G., Milanova, V., Sapunov, I., Tchoumatchenko, P. 1994. Geological Map of the Republic of Bulgaria in scale 1:100,000, Teteven Map Sheet. Committee on Geology, Company for Geophysical surveys and Geological mapping, Sofia.

CLC, 2012. CORINE LandCover dataset for 2000 and 2012 (http://land.copernicus.eu/pan-european/corine-land-cover/ clc-2012).

Eckhardt, K. 2005. How to construct recursive digital filters for baseflow separation. Hydrological processes 19 (2), $507-515$

Gregor, M. 2010. BFI+ User's Manual. HydroOffice, 21 pp. (http://HydroOffice.org).
Hubbart, J.A., Zell, C. 2013. Considering streamflow trend analyses uncertainty in urbanizing watersheds: a baseflow case study in the central United States. Earth Interactions 17 (5), 1-28.

Koleva, E., Peneva, R. 1990. Climatic reference book. Precipitation in Bulgaria. Bulgarian Academy of Sciences Publishing House, Sofia, 169 pp. (in Bulgarian).

Lim, K.J., Engel, B.A. 2004. WHAT: Web-Based Hydrograph Analysis Tool (https://engineering.purdue.edu/mapserve/ WHAT/).

Lim, K.J., Engel, B.A., Tang, Z., Choi, J., Kim, K.S., Muthukrishnan, S., Tripathy, D. 2005. Automated web GIS based hydrograph analysis tool, WHAT. Journal of the American Water Resources Association 41 (6), 1407 1416.

Martin, J.B., Screaton, E.J. 2001. Exchange of matrix and conduit water with examples from the Floridan aquifer. In: Kuniansky, E.L. (Ed), US Geological Survey Karst Interest Group Proceedings, Water-Resources Investigations Report 01-4011, 38-44.

Miller, M.P., Johnson, H.M., Susong, D.D., Wolock, D.M. 2015. A new approach for continuous estimation of baseflow using discrete water quality data: Method description and comparison with baseflow estimates from two existing approaches. Journal of Hydrology 522, 203-210.

Price, K. 2011. Effects of watershed topography, soils, land use, and climate on baseflow hydrology in humid regions: A review. Progress in Physical Geography 35 (4), 465-492.

Radulov, A. 2002. Karst spring of the Cherni Osam River - an alternative of the Cherni Osam dam. Geology and Mineral Resources 5, 14-18 (in Bulgarian).

Sloto, R.A., Crouse, M.Y. 1996. HYSEP: A Computer Program for Streamflow Hydrograph Separation and Analysis. U.S. 
Geological Survey, Water-Resources Investigations, Report 96-4040, Pennsylvania, 46 pp.

Spasov, V. 1966. Natural resources of groundwater in the zone of active water exchange in Northern Bulgaria. Travaux sur la géologie de Bulgarie, Séries géologie de l'ingénierie et hydrogéologie 5, 71-90 (in Bulgarian).

Wahl, K.L., Wahl, T.L. 1995. Determining the flow of Comal
Springs at New Braunfels, Texas. Proceedings of Texas Water 95 (6), 16-17.

Zinn, B., Harvey, C.F. 2003. When good statistical models of aquifer heterogeneity go bad: A comparison of flow, dispersion, and mass transfer in connected and multivariate Gaussian hydraulic conductivity fields. Water Resources Research 39 (3), 1051. 